\title{
Spationomy Simulation Game
}

\author{
Vít Pászto and Jiří Pánek
}

\begin{abstract}
The last part of the book is dedicated to the simulation game framework. What is meant by the simulation game within the Spationomy project will be described in the following Sect. 16.1. Conceptual thoughts, as well as the motivation and goals of the Spationomy simulation game, will be briefly introduced as well. Also, the overall theoretical framing about educational aspects of simulation games (or gamification in general) with a focus on geography or economy will be provided with the first section. After this introductory chapter, each of the Spationomy simulation game rounds will be described in detail and also original instructions assigned to the students will be presented (Sect. 16.2). The reason for this chapter is to give a chance to the reader to use, extend and employ these materials in his/her teaching activity. The last two chapters are devoted to feedback and evaluation of the simulation game. Section 16.3 is about teacher/
\end{abstract}

V. Pászto $(\bowtie)$

Department of Informatics and Applied Mathematics, Moravian Business College Olomouc, Olomouc, Czech Republic

Department of Geoinformatics, Palacký University Olomouc, Olomouc, Czech Republic

e-mail: vit.paszto@gmail.com

\section{J. Pánek}

Department of Development and Environmental Studies, Palacký University Olomouc, Olomouc, Czech Republic e-mail: jiri.panek@upol.cz project staff experiences during the creation of simulation game, playing the game itself, modifying it during its evolution and also about "what worked and what did not". In the same section (Sect. 16.3), we will provide the reader with students' feedback and evaluation. Students' authentic commentaries and suggestion are essential for further improvements of the game, and their insights also prove that the whole idea of making spatial economy playful is highly appreciated and fruitful. The main goal of Part IV of the book is to allow anyone to adopt and replicate the simulation game framework in the learning and teaching process.

\section{Keywords}

Playful learning · Gamification - Spationomy · Geography $\cdot$ Economy

\subsection{Spationomy Simulation Game Concept}

One of the Spationomy goals was to assess the potential of playful, experiential and simulation game-based learning in the context of interdisciplinary learning. By doing so, it was needed to establish a simulation game scenario to model real-world problems and their solutions. It turned out that this has been the greatest achievement of the Spationomy project so far and proves the fruitfulness of the project. Simulation gamebased learning appears to be much more playful 
and experiential compared to traditional teaching. Hence, participating students and also staff members have an opportunity to test out new methods and create outputs that are necessary to implement those methods. Within the simulation game, students learn and adopt joint methodologies, techniques, and tools. Students serve as actors in an economic/business analytics game with important spatial (geographical) aspects. The game is deployed to structure group-based and student-led investigations of advanced economic data analyses. Students are active agents in stimulating economic/business analytics issues from the real world via a series of game rounds. Unconventional learning in the simulation-based game entails more attractive and relevant pedagogy than lecture or seminar based approaches. Following sections allow readers to inhale basic principles of the simulation game in an educational context and to uncover key features and conceptual settings of the Spationomy simulation game.

\subsubsection{Theoretical Background}

The idea of the gamification of a learning process is not new in (higher) education. It was famous Czech philosopher and educator Jan Ámos Komenský (John Amos Comenius, 1592-1670), and his well-known work "Schola Ludus" (School by Play) in which he promoted an entertaining way of learning. Indeed, we all know that learning is easier if it contains playful features. It is then more pleasant to acquire new knowledge and to master our skills. If we dare to jump over several centuries into the twentieth century, we can find works and discussions of how simulations (in general) are used or could be used in (geographical) education. For instance, McCormick (1972) discusses the definitions of simulation and explains basic steps in the construction and application of simulation in education. He also mentions the broad definition of simulation formed by Twelker (1970) - simulation is a means for letting learners experience things that otherwise might remain beyond their imagination, a means to practise skills safely and without embarrassment, and perhaps even discover insights into actual problems. An essential aspect in this definition is the fact that simulation is a method by which the learner or participant can be involved at the centre of the problem under investigation (McCormick 1972). McCormick (1972) also notes very interestingly, and indeed a true aspect of simulation - the role of a teacher/ supervisor is blurred since there is no central element in simulations, and the main workload is then spread to learners (students). Moreover, participating students are much more "mentally" pulled into the simulation process, so they somehow tend to ignore (or mishear, better to say) orders from a teacher. As the Spationomy playful activity - the simulation game - contains both words "simulation" and "game", it is worth to mention the main difference between "simulation" and "game" (based on McCormick 1972; Abt 1969; Nesbitt 1971; Strum 1969). In general, when playing games, there is usually a set of firm rules based on which a winner is determined. In games, the key agents are competitors (individuals, teams, environments, computers), who strive to reach an objective (e.g. complete a game round task) with actions framed by pre-set rules. Moreover, a game often includes a feature to make it enjoyable for a player, while still serious enough to keep the attention and focus. As indicated above, there could be different types of competitors. Besides an individual or a human team player, we can play against ourselves, environment, or computer (artificial intelligence). Whereas the simulations do not necessarily produce a winner (winners). Simulation is more about the investigation of possible ways to solve a real-world problem. Both games and simulations include a very key element, which is decision making. Allowing a learner to make decisions is the most valuable attribute of playful teaching, and it encourages the participant to think and to act upon his/her conclusions (McCormick 1972). Playful methods, whether or not it is gaming or simulations, can be framed in a concept of "learning by doing", from which a learner can carry off more into his/her reality outside the school environment. Spationomy simulation game represents such a methodological 
approach. Moreover, it contains all four features of "games" as identified by Crawford (1982): Representation, Interaction, Conflict, and Safety. According to Egenfeldt-Nielsen et al. (2008), Representation means that games model external situations but they are not part of these situations. As Crawford (1982) states, a game subjectively represents a subset of reality. Interaction deals with a level of player engagement, and Conflict (direct or indirect) is the idea that a game has a goal that is blocked by obstacles (EgenfeldtNielsen et al. 2008), which are permanently present to stimulate the challenging nature of games. Finally, Safety feature in the games is about the fact that the actions taken during the game result into (game) situations that do not affect a player's real-life (i.e. destroying a car in a virtual race). Egenfeldt-Nielsen et al. (2008) refer to two accepted and short definitions of games. Salen et al. (2004) suggest that a game is a system in which players engage in an artificial conflict, defined by rules, that results in a quantifiable outcome, while Juul (2003) defines a game as a rule-based formal system with a variable and measurable outcome. More about gaming concept can be found in Egenfeldt-Nielsen et al. (2008), thus will not be further discussed here.

Games and simulations as teaching techniques were noticed in the late 1960s (e.g. the pioneering work by Gould 1963) and 1970s, and were treated as an innovative approach in the learning process (e.g. McCormick 1972). In geography, this was followed by descriptions of how games and simulations could be used in (tertiary) geography teaching. For example, Conolly (1981) describes how four different games were modified and integrated into geography classes at that time. Walford (1981) refers to how geographic games and simulations started replacing traditional teaching methods, which appeared to be dissatisfactory. Building on traditions of simulations (e.g. in management and business studies) and using experiential learning (see, e.g. Healey and Jenkins 2000) as a trend that days, Walford (1981) advocates how simulations and games are valuable in the learning process. He points out that games and simulations (1) improve student motivation, (2) create a better teaching atmosphere, (3) help to fulfil more rigorous and ambitious educational goals, and (4) encourage the more effective learning of subject-matter.

On the other hand, Walford (1981) critically argues the disadvantages of games and simulations, mainly its preparatory phase, de-briefing part, and overall fit into a study programme. In the same year as Conolly and Walford published their work, another author is touching the topic of games and experiential learning; King (1981) discusses "to play or not to play" in geography teaching. Interestingly, taking an example from Ancient Chinese proverb, King (1981) emphasise an act of "doing" as a way how to understand a problem under the investigation. In today's words, the "learning-by-doing" approach seems to be applicable with no regards to time (leading us back to the Czech philosopher Comenius and his "school by play"). Nowadays, there are a vast number of research papers and books is dealing with games and simulations connected with (geography in) higher education, and it is not the aim of this section to provide throughout list and review of them. However, it can be observed that modern technologies play an important role in the gamification of lectures. Typical ground-breaking product has been Google Earth and its set of satellite and aerial imagery, although not being a game nor simulation, rather "just" a tool. One of the most known examples of proper simulation games useful for geography teaching could be SimCity (e.g. Kim and Shin 2016) or Transport Tycoon (e.g. Minović et al. 2011, or Raghothama and Meijer, 2013). The latter connects simplified geographical environment, specifically transportation, with the business/economy and local geopolitics. It is also worth to mention a phenomenon developed in 2009 - Minecraft (e.g. List and Bryant 2014; Nebel et al. 2016; Scarlett 2015). This platform can very effectively serve as a learning tool, and Microsoft released Minecraft's educational version in 2016. A detailed study on how Minecraft is used in education and research is provided by Nebel et al. (2016). In the last 5 years, significant proliferation of augmented and virtual reality applications into education has taken place; and it seems that such tools and 
applications will be a flagship in modern playful teaching methodologies.

As regards (pure) business simulation games, a comprehensive overview of such games is given in an article by Faria et al. (2009). The authors explored papers published in the Simulation \& Gaming journal, where they mention the most important advancements in business gaming in the history of the last 40 years before 2008 . Authors touch the topics covering technology of business games, how business games were administered, and about current (note in 2008) nature of business simulation games. Interestingly, Faria et al. (2009) note that other researches traced a history of business games back nearly 5000 years when the first board and war games were developed. The first modern business simulation game was developed by Mary Birshtein (Russia) in 1932. The "game" simulated the assembly process at a typewriter factory to train managers on how to handle production problems (Gagnon 1987). On the other side of the Globe, in Northern America, the first business simulation game was launched in 1955, when RAND Corporation (prestigious American research institution) came with simulation application focusing on U.S. Air Force logistics system. The exercise goal was to train participants as inventory managers in a simulation of the Air Force supply system (today, it is a typical example of the role of business managers). Since then, a vast number of business simulation games were developed (including more than 40 versions of Mary Birshtein's game). In 1961, it was estimated that more than 100 business games were in existence in the United States; as for 1969 there were more than 190 business simulation games, and in 1980 around 230 business simulation games in use in the United States (Faria et al. 2009). Faria et al. (2009) also report that in Eastern Europe in 1980, more than 30 business simulations were used, and approximately 200 business games were in use in German-speaking countries in 1985. Table 16.1 summarises the most significant in the history of business simulation games as mentioned by Faria et al. (2009).

As mentioned by Raphael Heath (Head of Geography, Royal High School Bath), in his presentation for Geographical Association Conference workshop 2017 (Heath 2017), the most important reasons to use games in education (in this case of geography education, but it also applies for other fields) are (1) Active and fun lesson activities, (2) Creating a memorable experience for students, (3) Develop a range of skills discussions, numeracy, teamwork, negotiation, problem solving etc., (4) Promotes thinking skills, (5) Opportunities for gaining knowledge through discovery and experience, (6) Engaging for students and simulating realistic experiences,

Table 16.1 Major business simulation games in the twentieth century

\begin{tabular}{l|l|l}
\hline Name & Developer & Year \\
\hline Birshtein's simulation game & $\begin{array}{l}\text { Mary Birshtein (Bureau for the Scientific Organization } \\
\text { of Work) }\end{array}$ & 1932 \\
\hline Monopologs & RAND Corporation & 1955 \\
\hline $\begin{array}{l}\text { Top Management Decision } \\
\text { Simulation }\end{array}$ & American Management Association & 1956 \\
\hline Business Management Game & Greene and Andlinger (McKinsey \& Company) & 1957 \\
\hline $\begin{array}{l}\text { Top Management Decision } \\
\text { Simulation }\end{array}$ & University of Washington & 1957 \\
\hline $\begin{array}{l}\text { New York University Business } \\
\text { Game }\end{array}$ & New York University & The 1970 s \\
\hline Imaginit & Barton & 1974 \\
\hline Compete & Faria, Johnstone, \& Nulsen & 1974 \\
\hline Capstone & Capsim Management Simulations, Inc. & $1985 / 1998$ (online) \\
\hline Marketplace & Innovative Learning Solutions, Inc. & $\begin{array}{l}\text { The 1990s (computer } \\
\text { version) }\end{array}$ \\
\hline
\end{tabular}

Source: Faria et al. (2009) 
and (7) Developing increased empathy with issues.

Heath (2017) also identifies some drawbacks connected to the gamification of lectures. It is often (1) time consuming to create a new own gaming lecture, (2) it takes time and resources to produce sets of games, (3) it consumes lots of lesson time and sometimes needs longer than lesson periods, (4) organising the classroom space and design for a game or finding an ample space to conduct it might be difficult, and (5) learners' behaviour management could also be challenging.

There exist plenty of games with educational and geographical context, both online and offline, for example, as board games or in-class-played games. These games strive to encourage learners to adopt terminologies, geographic names, or to improve spatial thinking. Some of the activities are not even games in their true meaning, such as GeoGuessr, Kahoot, Qiuzlet or other quiz-based games. However, we mention three most interesting simulation games, two of them are online, and one is the analogue board game. By accident, the first two of them deal with disaster management, where geography plays a dominant role though; and the third game is about energy transition (from fossil to renewable sources of energy, and energy savings) and decision making in spatial planning. Firstly, the Playgen company, settled in the United Kingdom, created and runs a simulation application called FloodSim. This game focuses on the implementation of various measures (e.g. building on-site flood barriers, rising citizen awareness about floods, applying governmental policies etc.) to prevent and minimise flood damage (Fig. 16.1).

Secondly, the Stopdisasters is an initiative and online game from the United Nations Office for Disaster Risk Reduction (UNISDR). Five game modes/scenarios can be played - hurricane, floods, earthquake, wildfire, and tsunami. Moreover, it is possible to adjust scenarios geographically (e.g. Europe, Asia, Australia) which gives a better context for learners and helps them to understand the risks in their local settings (see floods in the European context in Fig. 16.2). Lastly, there has been a paper recently published by Ampatzidou and Gugerell (2019) about a serious game called Energy Safari to support learning

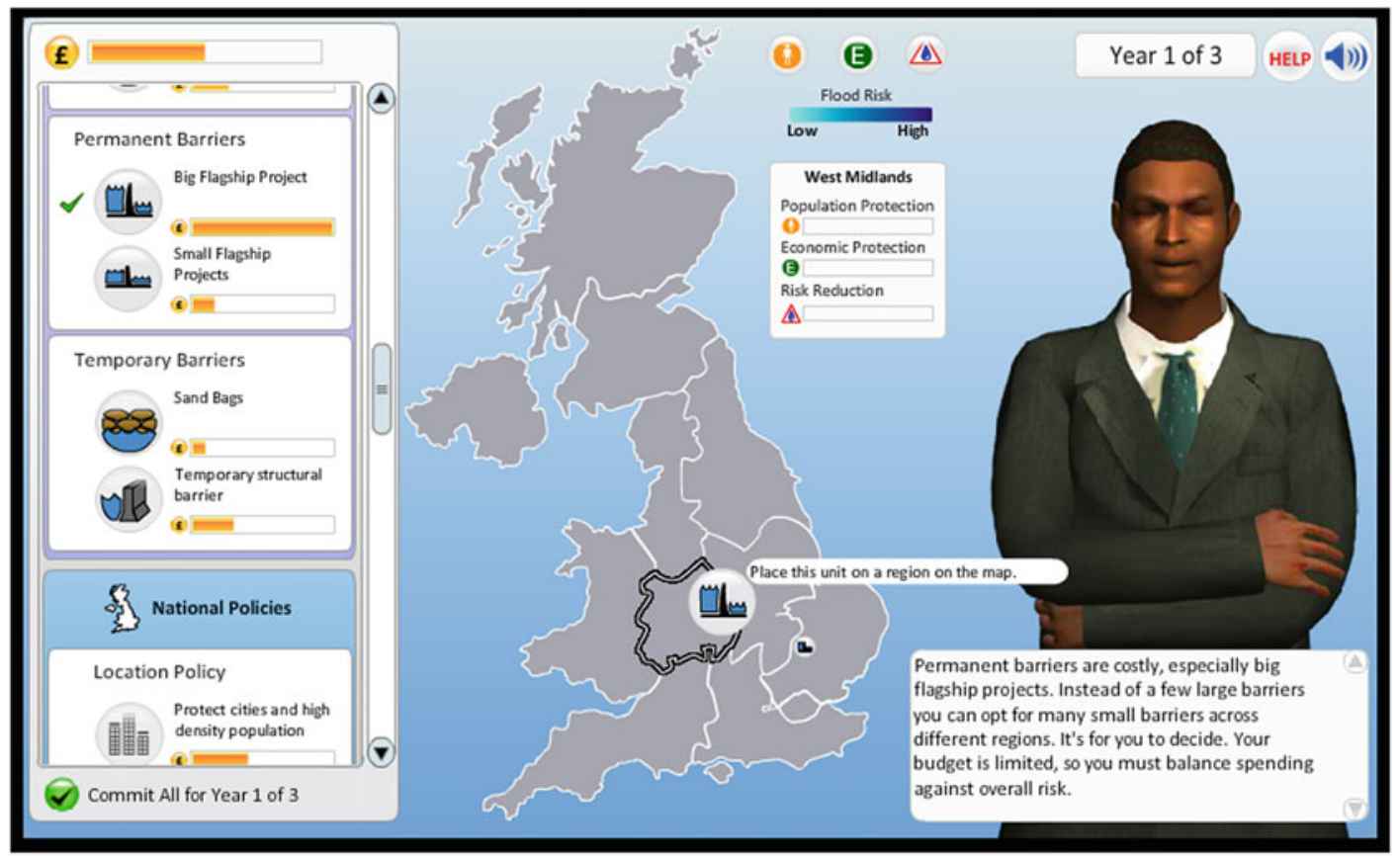

Fig. 16.1 The user interface of the first round in the FloodSim simulation game. (Source: playgen.com/play/floodsim) 


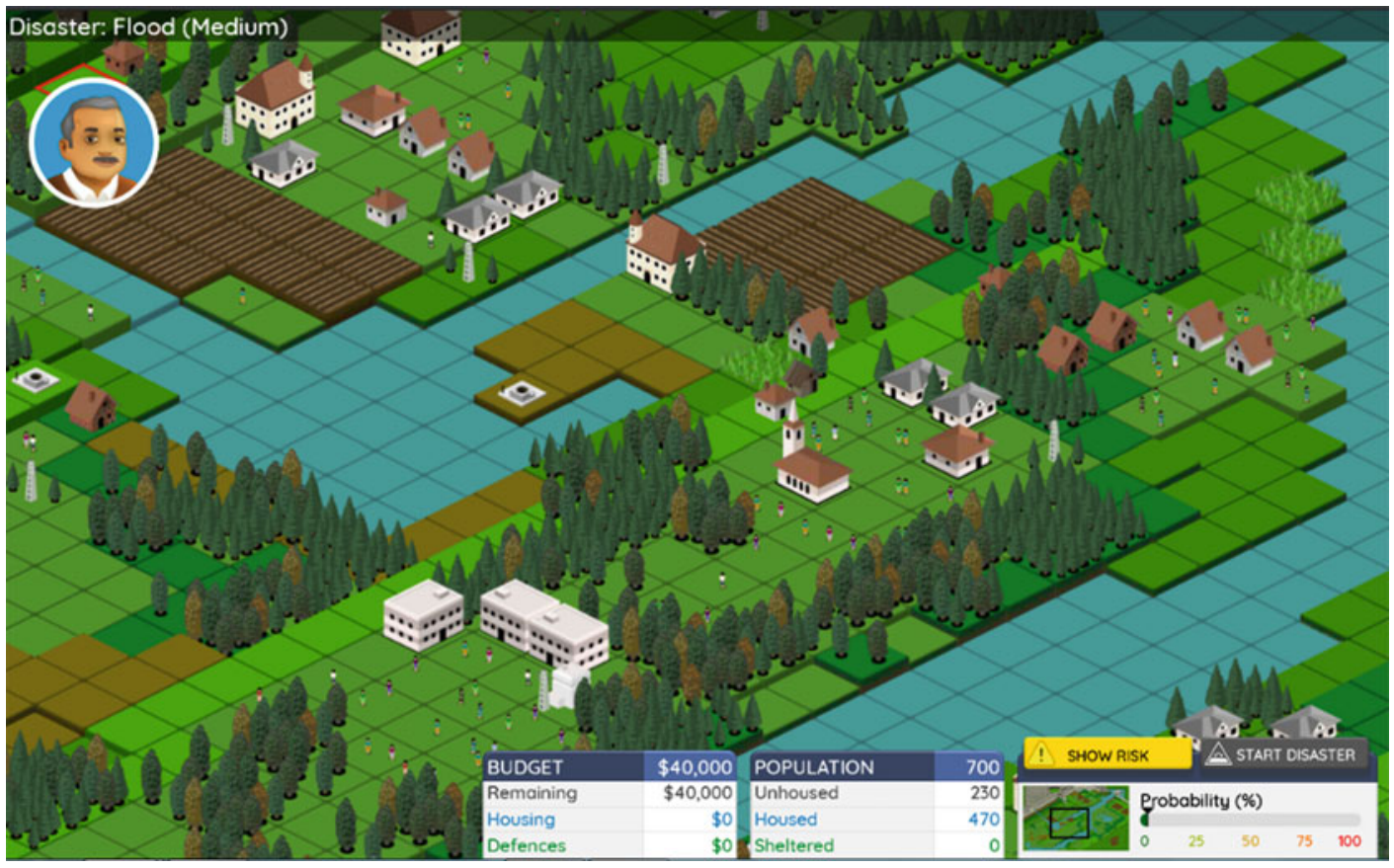

Fig. 16.2 Gaming environment in the Stopdisasters game in the topic of floods in Central European settings. (Source: stopdisastersgame.org)

processes in urban and spatial planning when it comes to a renewable energy and energy savings encouragement. The game board is an abstract map divided by a square grid (similarly as in Stopdisasters - Fig. 16.2) into different policy areas, players roll dice to move with their avatar, and there are also special action cards that influence the game. This game is a very good example of how complex topics can be presented in playful settings.

\subsubsection{Spationomy Simulation Game Key Features}

This section summarises the main features of the simulation game - from the students' teams preparations, through initial simulation game settings, time management of the game, to scoring and ranking system. But firstly, we need to note that it had to cover as many (positive) points made by Heath (2017) mentioned in the previous section. Apart from traditional teacher-focused classes, students were involved in an activity that requires their full participation and engagement, which makes their learning process more effective and fun. Connected to that, students also create memorable experiences by being infused into a simulation game momentum. The gaming settings of a learning process give the students a chance to promote and enrich their skills and team thinking. Often, without knowing it, students develop a range of skills - discussions, brainstorming, team decision making, problemsolving, or time management - by playing a simulation game. And since the Spationomy simulation game combines a thematic focus from geography, geoinformatics, economy, business informatics, management and others, students gain skills by discovering and experiencing realworld issues simulations.

Before students play the Spationomy simulation game, they gain a necessary skill set in previous parts of the Spationomy cycle. Since the simulation game represents the very final activity of the one Spationomy cycle (preceded by an 
intensive lecture week, semestral project elaboration, and workshops during a summer school), students are stimulated enough to be able to play the game. Students' knowledge and skills gradually increase as the project activities evolve, which allows them to be fully equipped for the game itself. Students are also instructed what is required from them and how they should perform to maximise their learning outcomes. The simulation game represents a final and most comprehensive activity where students apply everything practically what they previously learnt.

From the very beginning of the joint gathering during the preparatory intensive lecture week (a drill part), students are divided to form an international team (a four-member team consists of one student per each partner university). This international setting also enables to work in an interdisciplinary environment, as each student possesses a different specialisation. Moreover, students are also mixed from the perspective of being in various stages/levels of their study. Some of the students just begin their studies, while others nearly finish and graduate, which leads to an exciting interaction within the team when it comes to individual team member roles. On top of it, less experienced students can learn from those with more experiences, and vice versa - younger students often come with less "distorted" ideas by their ongoing studies, albeit sometimes a bit naïve, however somehow inspiring their older colleagues.

The thematic of the simulation game rounds is designed in a way that keeps a balance between "geographical" and "economic" focus. That is ensured by sharing responsibilities within the staff team, so every project partner designs an independent and versatile simulation game round. All simulation game rounds (except the initial setting-up round) are created in a way that allows them to be played at any stage of the game - the rounds are not dependent on previous (or next) round which gives them desired versatility.

From the technical point of view, computers are a necessary precondition of the simulation game. Either more geographically or economically oriented round requires specific software tools. Thus, any means of an electronic device with such tools is inevitable. From the geographical perspective, students mostly work within Geographical Information System environment (such as ArcGIS for Desktop, or QGIS). For the other tasks from the economic and management part, students use table editors (such as Google Sheets, MS Excel, Open Office), statistical/computational software (e.g. R-Project, or SPSS), and for design, a variety of desktop and offline tools are employed. For most of the rounds, there is no limitation on a specific software tool usage and students can decide on their own what tools they prefer.

As regards the simulation game timing, every round lasts around 90 minutes in which students must deliver the required output. The only exception is the initial round that lasted a half-day (i.e. $180 \mathrm{~min}$ of lecture time) where students need to solve more tasks, specifically to find an optimal location for their business factory, to decide on a number of employees, or to design their corporate identity. This time settings lead to a two-day gaming session. As indicated above, after each round, students have to report their progress by sharing the required output with game masters (staff members). Depending on a type of the round, students provide a map project, pictures, presentations, results of the deal with another team, or "just" numbers (based on calculations in given rounds) and so on. All these outputs are double-checked by the game masters and creators of the given game round with the use of a simple and single table to keep the scoring transparent and clear (see example in Fig. 16.3).

It must be emphasised that the students' teams compete with each other to win the game. The winning team was ensured by defining objective measures (scores) which serves as a proxy for overall rankings. However, sometimes it is not possible to obtain numeric scores for certain game rounds. Therefore, game masters (staff members) collectively and expertly rank the 


\begin{tabular}{|c|c|c|c|c|c|c|c|c|c|c|c|c|c|c|c|c|c|c|}
\hline \multirow{2}{*}{$\begin{array}{r}\text { Team } \\
1\end{array}$} & \multicolumn{2}{|c|}{$\begin{array}{l}\text { Heritage } \\
\text { (START) }\end{array}$} & $\begin{array}{l}\text { Size } \\
\mathrm{m} 2\end{array}$ & $\begin{array}{l}\text { EMP } E \\
\min n\end{array}$ & $\begin{array}{l}\text { EMP } \\
\max \end{array}$ & Empl S: & Salaries & \multicolumn{2}{|c|}{ Operational } & Production & tion $\mathrm{Pr}$ & Price & \multicolumn{2}{|c|}{ Sales } & Pollution & Investments & \multicolumn{2}{|c|}{ Cash balance } \\
\hline & \multicolumn{2}{|c|}{$3000000 €$} & 350 & 35 & 105 & 100 & $1119600 €$ & \multicolumn{2}{|r|}{$951660 €$} & & 1200 & $2100 €$ & \multicolumn{2}{|c|}{$3024000 €$} & 1200 & $182000 €$ & \multicolumn{2}{|c|}{$3770740 €$} \\
\hline 2 & \multicolumn{2}{|c|}{$3000000 €$} & 680 & 68 & 204 & 79 & $884484 €$ & \multicolumn{2}{|r|}{$751811 €$} & & 948 & $2100 €$ & \multicolumn{2}{|c|}{$2388960 €$} & 948 & $82126000 €$ & \multicolumn{2}{|c|}{$1626665 €$} \\
\hline 3 & \multicolumn{2}{|c|}{$3000000 €$} & 700 & 70 & 210 & 200 & $2239200 €$ & \multicolumn{2}{|c|}{$1903320 €$} & & 2400 & $2100 €$ & \multicolumn{2}{|c|}{$6048000 €$} & 2400 & $770000 €$ & \multicolumn{2}{|c|}{$4135480 €$} \\
\hline & \multicolumn{2}{|c|}{$43000000 €$} & 342 & 34 & 102 & 100 & $1119600 €$ & \multicolumn{2}{|r|}{$951660 €$} & & 1200 & $2100 €$ & & $898000 €$ & 1200 & $547 / 200 €$ & 3279 & $540 €$ \\
\hline 5 & 30000 & $100 €$ & 51 & 5 & 15 & 10 & $111960 €$ & & $95166 €$ & & 1202 & $2300 €$ & & $331200 €$ & 120 & $44460 €$ & 3049 & $614 €$ \\
\hline 6 & 30000 & $00 €$ & 180 & 18 & 54 & 21 & $235116 €$ & & $199849 €$ & & 2522 & $2200 €$ & & $637560 €$ & 252 & $547200 €$ & 2655 & $395 €$ \\
\hline 7 & 30000 & $00 €$ & 5574 & 557 & 1671 & 1842 & $2060064 \varepsilon$ & & $751054 €$ & & $2208 \quad 2$ & $2100 €$ & & $332320 €$ & 2208 & $1449240 €$ & 3071 & $962 €$ \\
\hline Assets & & $\%$ & Opera & ational & Cash & $\%$ & Employees & $\%$ & Pollu & lution & L & $\begin{array}{l}\text { Location } \\
\text { bonuses }\end{array}$ & $\%$ & 6 & Cash balánce & Total & & ANK \\
\hline 182 & $2000 €$ & $9 \%$ & & 9527 & $740 €$ & $50 \%$ & $1 \%$ & 100 & $50 \%$ & 1200 & $10 \%$ & & 0,2 & $100 \% 3$ & $3770740 €$ & $91,2 \%$ & $310 \%$ & 4 \\
\hline 2126 & $6000 €$ & $100 \%$ & & 7526 & $665 €$ & $40 \%$ & & 79 & $40 \%$ & 948 & $13 \%$ & & 0,2 & $100 \% 1$ & $1626665 €$ & $39,3 \%$ & $331 \%$ & 3 \\
\hline & $0000 €$ & $36 \%$ & & 19054 & $480 €$ & $100 \%$ & & 200 & $100 \%$ & 2400 & $5 \%$ & & 0,2 & $100 \% 4$ & $4135480 €$ & $100,0 \%$ & $441 \%$ & 1 \\
\hline 547 & $7200 €$ & $26 \%$ & & 8267 & $740 €$ & $43 \%$ & & 100 & $50 \%$ & 1200 & $10 \%$ & & 0,15 & $75 \% 3$ & $3279540 €$ & $79,3 \%$ & $283 \%$ & 6 \\
\hline & $4460 €$ & $4 \%$ & & 1240 & $074 €$ & $7 \%$ & $\%$ & 10 & $5 \%$ & 120 & $100 \%$ & & 0,2 & $100 \% 3$ & $3049614 €$ & $73,7 \%$ & $289 \%$ & 5 \\
\hline 547 & $200 \mathrm{C}$ & $26 \%$ & & 2025 & 5956 & $11 \%$ & & 21 & $11 \%$ & 252 & $48 \%$ & & 0,15 & $75 \% 2$ & $2655395 €$ & $64,2 \%$ & $234 \%$ & 7 \\
\hline 1449 & $9240 €$ & $68 \%$ & & 5212 & $202 €$ & $80 \%$ & & 184 & $92 \%$ & 2208 & $5 \%$ & & 0,15 & $75 \% 3$ & $3071962 €$ & $74,3 \%$ & $395 \%$ & $\underline{2}$ \\
\hline
\end{tabular}

Fig. 16.3 Illustration of the scoring system complexity managed in a simple template using tabular software. (Source: Authors)

students' teams in those specific rounds. In the end, the best team is announced and wins the simulation game.

\subsection{Simulation Game Rounds}

The initial story that students work with is that they virtually inherit a certain amount of money from their ancestors. They have various tasks (mandatory and voluntary) to invest money from the inheritance. They are obliged to buy retail properties with a specific function. Students use spatial analyses (location and allocation analyses) to choose the best place within the area of interest (city or large town). Simulation game goes on with "accidental" events happening (organised in an individual game round) - such as natural hazards (floods), drops of economic parameters (economic crisis) and so on. They have to apply spatial and economic knowledge, skills, and tools to cope with the newly emerged situation. The simulation game-based learning is focused on the practical application of geospatial tools as well as quantitative economy skills and knowledge to solve given tasks. Each project year/cycle, the game contained several rounds.

In this chapter, we will shortly describe the setting of each round that was played during the first two years/cycles of the Spationomy project. In the next paragraphs, we will present what information was given to the students and what deliverables we expected. During the first year, students had a chance to play four rounds of the simulation game. In the second year of the project, the simulation game was extended and played in six rounds in total. Some of the rounds from year one were also used in the second year, while we added some brand new rounds to enrich the simulation game. The whole simulation game was geographically situated in Olomouc (hometown of the two Czech Spationomy partners) see overview map for the initial round (Sect. 16.2.1) in Fig. 16.4. The rounds here are presented exactly in the form they were given to students. 


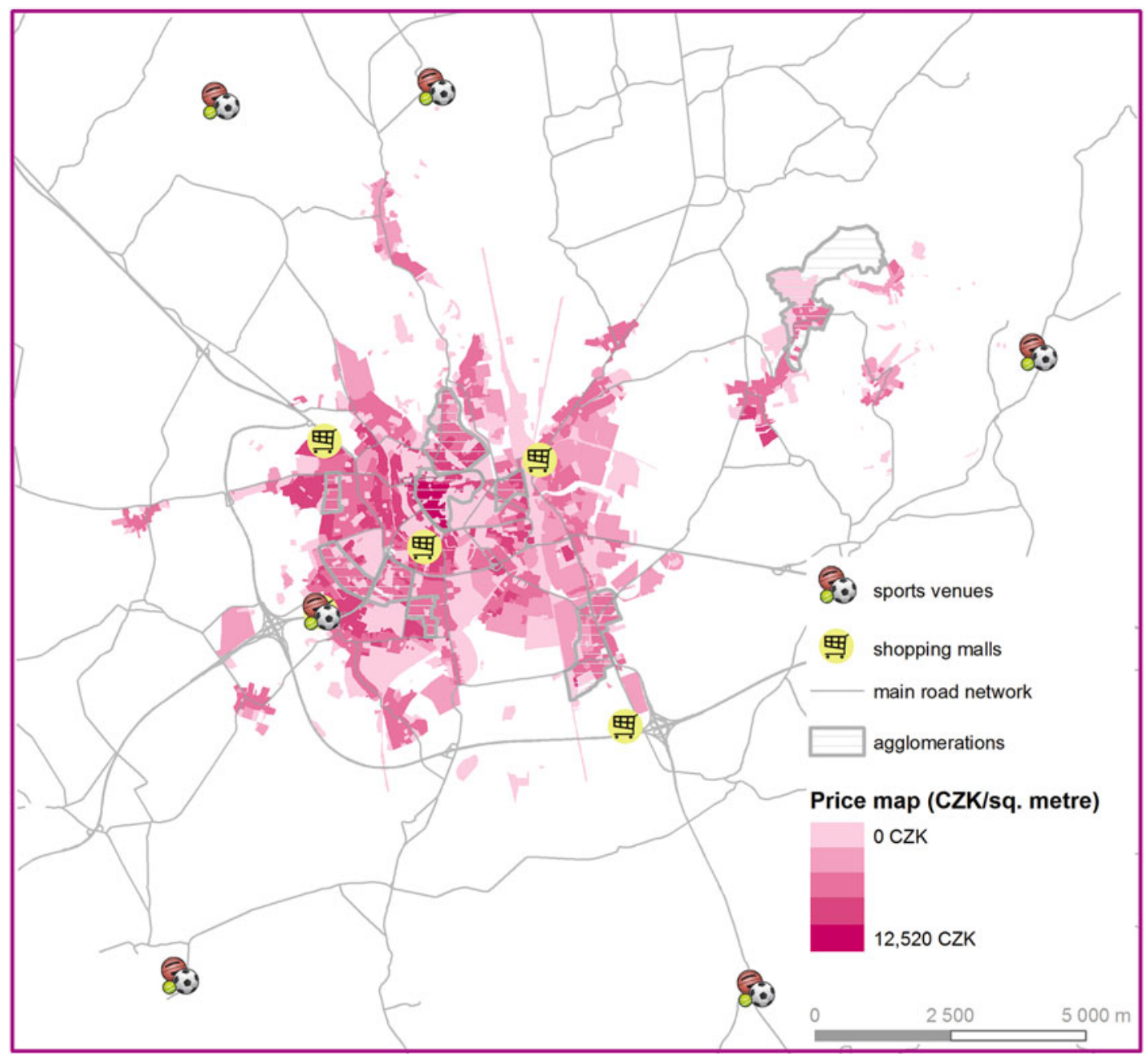

Fig. 16.4 Geospatial setting an overview for the first round. (Source: Authors)

\subsubsection{Establishing a Bicycle Company}

Each year, this was the starting round where students were allocated a budget, and their task was to find a suitable location for building new bicycle factory, as well as choosing the size/production capacity of the factory. Their initial allocation decision affected the rest of the game and their success in the simulation game. Students were not aware of what are the next rounds/ tasks within the game, in order not to suggest any locations within the city.

\subsubsection{Abstract}

You inherited 3,000,000 EUR from your grandmother, who was a successful bicycle racer. Her last wish was that you would establish a bicycle enterprise producing brand new and modern bicycles. The round number 1 of the simulation game is a ,set-up“ round in which you will decide on the location, size, production, name and brand (marketing) of your bicycle enterprise. Round 1 is about strategy, (spatial) planning, and teamwork, aiming at the decision-making process within your team. Following rules/tasks are obligatory, 
and you need to decide which way to go. Your decisions made in this round will have an impact on your business throughout the simulation game. So better think twice.

\subsubsection{Set-Up Rules}

- To build one square meter of your factory costs you an amount according to zones of a price map of Olomouc (see Fig. 16.4)

- Build the enterprise manufacture hall using the zones of price map:

- you are not allowed to build the enterprise on the roads/railways/rivers/lakes/no-gozone and other places generally not suitable/accepted (use your common sense)

- if you plan to build the enterprise in an "open space" area (field, non-urbanized area etc.), you need to pay the price for a square meter according to the price map

- you can build the enterprise in a place where the other building(s) already exist (according to the aerial image), but you need to buy up the property first (according to the price map) and then pay the price for a square meter according to the price map. In other words - you need to pay twice

- if your enterprise is located in two or more land prices parcels, you need to calculate the cost by respective parts for each piece according to the land price map

- if there is no data about the land prices, the median price $(1,100$ EUR) is paid

- Only one storey manufacturing halls are allowed and should be a rectangular shape.

- Every $10 \mathrm{~m}^{2}$ need at least one employee, but a maximum of 3 employees per $10 \mathrm{~m}^{2}$ are allowed (three-shift work).

- You will pay your employees an average monthly wage in the Olomouc region which is 933 EUR.

- One employee can produce one bicycle per month.

- One bicycle is sold for:

- 2,300 EUR if you are micro-sized enterprise

- 2,200 EUR if you are small-sized enterprise

- 2,100 EUR if you are medium-sized enterprise
- Operational expenditures (other than salaries) are $85 \%$ of wages per year.

- Factory is producing pollution. The total amount of pollution is: no. of bicycles made per year $* 1$ ton.

- At the end of the second round, you can change the number of employees.

- Your enterprise will be categorised into three classes:

- Micro-sized (no. of employees up to 10)

- Small-sized (no. of employees up to 50)

- Medium-sized (no. of employees up to 250)

\subsubsection{Bonuses}

Find a location for your enterprise.

- Closeness to the main road network (according to the centroid of the manufacture):

- up to $100 \mathrm{~m}$ - annual income from sales increase by $10 \%$

- up to $150 \mathrm{~m}$ - annual income from sales increase by $5 \%$

- more than $150 \mathrm{~m}$ - no annual income increase.

- Closeness to market (agglomerations, sports venues and shopping malls):

- up to $100 \mathrm{~m}$ - annual income from sales increase by $10 \%$

- up to $250 \mathrm{~m}$ - annual income from sales increase by $5 \%$

- more than $250 \mathrm{~m}$ - no annual income increase

\subsubsection{Marketing}

- Create the name of your company.

- Create a motto for your company.

- Design a logo of your company.

- Create a dashboard for your company.

\subsubsection{Data}

Spatial data are available on the Spationomy website. Economic data are to be derived from your enterprise settings. 


\subsubsection{Deliverables}

At the end of this round, you will provide us:

- size and location of the manufacture (ideally a map).

- economic indicators (preferably in Excel):

- number of employees (and sum of their salaries)

- cash balance

- pollution amount (in tons)

- investments (money invested in building your manufacture)

At the beginning of the second round (the other day morning), you will provide us:

- marketing part (name, motto, logo, dashboard)

\subsubsection{Floods}

Historically, Olomouc was hit by several severe floods in the past 30 years. Hence one of the rounds was the simulation of a natural disaster of this kind. We took the flood zones from 1997 (the largest floods in the modern history of the city) and slightly expanded the flooded areas. This task included two sub-tasks:

- geographical - finding the optimal evacuation route

- economic - calculating the cost of floods on the factory and production

This round combined economical as well as the geographical background of our students, the same way as the whole Spationomy project is designed.

\subsubsection{Abstract}

The floods have come. This disaster was caused by the combination of extreme spring rainfall and saturated soils from previous snow melting. The hazard was magnified by the incomplete antiflooding system in the region. You need to calculate how much do floods affect your company according to the rules below. Moreover, you must evacuate the employees of your company to the evacuation centre with minimal costs.

\subsubsection{Rules for Floods Damage}

Floods are affecting your enterprise in this way:

- If your company is located in Zone 1 (the most severe damage):

- your annual production decreased by $50 \%$

- you need to repair your manufacture with the cost of $20 \%$ of your initial investment (i.e. you pay $20 \%$ of the manufacture price)

- your pollution amount decreased by $50 \%$

- If your company is located in Zone 2:

- your annual production decreased by $40 \%$

- you need to repair your manufacture with the cost of $10 \%$ of your initial investment (i.e. you pay $20 \%$ of the manufacture price)

- your pollution amount decreased by $40 \%$

- If your company is located in Zone 3:

- your annual production decreased by $30 \%$

- you need to repair your manufacture with the cost of $0 \%$ of your initial investment (i.e. you do not have to pay anything)

- your pollution amount decreased by $30 \%$

- If your company is located in Zone 4 (no floods at all):

- your annual production decreased by $10 \%$

- you need to repair your manufacture with the cost of $0 \%$ of your initial investment (i.e. you do not have to pay anything)

- your pollution amount decreased by $10 \%$

\subsubsection{Rules for Evacuation}

You need to find the cheapest way to any of the evacuation centres:

- If you are in Zone 1, 2 and 3 you must evacuate your employees from the manufacture to the evacuation centre at minimal costs.

- If you are in the Zone 4, you do not have to evacuate any of your employees, but you need to bring them to your manufacture from the evacuation centre at minimal costs, which is then halved. 
One employee to evacuate costs you

- 0.5 EUR per kilometre

- 4 Cents per second

- The formula for calculation is:

- number of employees * (no. of kilometres $* 0,5 \mathrm{EUR}+$ no. of seconds $* 4$ Cents)

Floods are affecting the road network in this way:

- All roads located in Zone 1 (the most severe damage):

- transportation speed decreased by $90 \%$ of the maximum allowed speed

- All roads located in Zone 2:

- transportation speed decreased by $75 \%$ of the maximum allowed speed

- All roads located in Zone 3:

- transportation speed decreased by $50 \%$ of the maximum allowed speed

- All roads located in Zone 4 (no floods at all):

- transportation speed stays the same as maximum allowed speed

\subsubsection{End of the Round}

- You can change the number of employees

- You need to recalculate all of the indicators

\subsubsection{Pollution Allowances}

Another round of our simulation game was designed the way so students can experience some action and bargaining about the pollution allowances. The whole round simulated the real events regarding the allowances distribution. According to the evaluation (see below in Sect. 16.4 in this part) the pollution allowances round was one of the most playful and successful.

\subsubsection{Abstract}

Your production is also a source of emissions of pollutants - greenhouse gases $\left(\mathrm{CO}_{2}\right)$. Government of your country decided to introduce new environmental legislation. Currently, you are involved in the Olomouc Emission Trading System, and you must decide how you will balance your environmental and economic indicators. The emission limit for the whole area is $70 \%$. There is no time for environmental investments to reduce emissions (e.g. ecological improvements).

You must buy emission allowances in auctions from the state (environmental exchange) to cover all of your emission by allowances. You are obliged to cover all of your pollutions by emission allowances, or you will be penalised.

You are producing the amount of pollution according to your production of bicycle (1 bicycle $=1$ ton). Your production of pollution is the same as before floods (your company has fully recovered from the floods).

\subsubsection{Sub-round 1}

\section{Auction (15 min)}

- You will join the exchange market and try to buy emission allowances in the auction. The officer will sell only $70 \%$ of pollution emission allowances. Your production of pollution is the same as before floods (your company has fully recovered from the floods).

- Firstly, in your team, you should discuss the price you will offer in the auction. The minimum bid is the current price at the real exchange market that is 5 EUR per ton. You should also discuss the number of emission allowances you would like to buy (1 emission allowance can cover one ton of pollution).

- You will offer your bid to the exchange market officer. You do not know the offers of other groups.

- After all, bids are made, the auction will be closed, and the officer will sell the allowances.

- Not all groups (companies) will obtain the emission allowances they need to cover their pollution production - the officer will sell the emission allowances to the bidders with the highest bids (price per ton). If there are two (or more) equal bids, the time/order of the bid is decisive. 
- You can also speculate - to buy more allowances than you need and try to sell them to other groups in the next round.

- As soon as you are ready to bid, come to the exchange market officer with your offer.

\subsubsection{Sub-round 2}

Spot Market (30 min)

- As a reminder - you are obliged to cover all of your emissions by emission allowances. In case you have not enough allowances for your emissions, you will pay sanctions to a government regulator. You can try to buy emission allowances from other groups.

- If you have a deal with the other group(s), you have to come to the exchange market officers to register you deal/trade.

\subsubsection{Sanctions}

Olomouc government decided to introduce sanctions per 1 ton of $\mathrm{CO}_{2}$ for those companies who did not cover all of the pollutions with their allowances. The sanction is 200 EUR per ton. The sanctions will be calculated at the end of this round.

\subsubsection{Market Share}

The topic focuses on the application of gravity modelling, namely the Huff gravity model within a GIS environment. The tool enables to calculate "service" areas of given event points (bicycle factory locations in this case) and also to include potential new location of another company branch to recalculate the new services areas (market share). The idea of this round was that every team could extend its market share (service area) by moving or splitting their current factory location. However, teams should also take into account the other teams' possible moves, so this round also supports strategic decision making and anticipation of other's behaviour.

\subsubsection{Abstract}

Your company is in the process of expansion, and you want to increase your market share. Your task is to calculate a service area of all the companies using gravity modelling to see what is your market share, i.e. how big is your service area at the moment.

You can temporarily change the location of your company into up to three sub-branches respecting the total "attractiveness" of your company in terms of annual bicycle production. Your market share will be evaluated based on the new customers you gain by changing/not changing the location of your company.

\subsubsection{Example}

The company produces 100 bicycles, which is the attractiveness measure. I want to split it into two sub-branches with new "attractiveness" of 40 and 60 bicycles. And I choose the location for both sub-branches.

Huff Model Settings (for the GIS Plugin)

- Store attractiveness field: production

- Distance calculation: leave blank

- Huff model options

- distance friction coefficient: 2

- Generate Market Areas: BOTH

- Generate probability surfaces: yes

- Origin Locations and Sales Potential Districts_Olomouc + Pop density

\subsubsection{Deliverables}

After you decide on your strategy, you will provide us with the spatial data (point layer) about the location(s) of your sub-branches with given attractiveness (production number) in the attribute table.

\subsubsection{Location for Reseller Shop}

One of the most common geospatial tasks is to find an optimal location for placement of a new shop, cash machine, new house etc. Location 
analysis provides tools to select the optimal location for such purpose based on given restrictions/ limits (e.g. $100 \mathrm{~m}$ from the road, on a slope less than $10 \%$ and so on). Geographical information systems allow performing such analysis very effectively and precisely. This round was mainly geographically-focused, therefore more demanding for "geo" team members of the student teams.

\subsubsection{Abstract}

The sale of your bikes is running not too bad, but since your competitors are not asleep and the different brands are flooding the stores, you had the idea to make the experience of shopping your bikes more special and unique and decided to start selling your bikes in your very own reseller shops.

To find a suitable location for your first shop, there are several requirements that need to be fulfilled to make sure that you reach as many customers as possible. As you cannot be sure that your rival companies have the same idea and the number of suitable sites is limited, there is no time to outsource the site analysis what forces you to do the calculations on your own. And you better do it fast. Sold stores are off the market, and you can only get what is left.

The rush on properties is at this moment declared to be open - hurry up!

\subsubsection{Requirements and Rules for Finding a Location for your First Shop}

- A new shop has to be located in a district with more than 3000 inhabitants per square kilometre

- A new shop has to be located within a distance of $250 \mathrm{~m}$ to roads of network class 1,2 or 3

- Size of the floor area of the new shop has to be between 400 and $1000 \mathrm{~m}^{2}$

- Permitted types of use for buildings:

- commercial

- garage

- industry

- other

- Locations will influence each other because the choice of a site by another group can reduce the catchment area of the site chosen by you.

- The customer potential for your site will be calculated in a number of inhabitants within Voronoi polygons processed using the locations of all groups and existing shops.

- The price for the new site depends on the size of the floor area multiplied by the price identified in the price map (round 1).

- The income will be calculated depending on the total number of inhabitants within the catchment areas.

- Sold stores will be displayed immediately on the projector.

\subsubsection{Deliverables}

Once you decide on the location of the new shop, come to the game masters to report your new location (providing spatial data in shapefile or geodatabase).

\subsubsection{Investment into Renewable Energy Sources}

This round focuses on a decision making the process of the team based on quantitative methods used for investments and their revenues. As this round is focused mostly on economic issues, the "economic" members of the team will take actions. However, decision making must be done collectively within the team.

\subsubsection{Abstract}

Green energy comes from natural sources such as sunlight, wind, rain, tides, plants, algae and geothermal heat. These energy resources are renewable, meaning they are naturally replenished.

As investment in green energy is more accessible than ever before, your task is to invest in selected green energy. Below is data about investments into solar plant and wind power plant. Your company has received two competitive offers for solar power plant and one offer for wind power plant. Accounting department had already prepared investment plans. Cash flows 
are based on solar plant/wind power plant efficiency (see geo-part for determination of effectiveness depending on the geographical position of your company). As manager of a company, you need to select the best provider (supplier). Expected rate of return (discount rate) is 6\%. Take into account that your company can sell the solar/wind equipment as scrap material at the end of investment maturity, for $10 \%$ of starting investment amount.

\subsubsection{Data about Solar Power Plant Investment Options (Alternatives)}

\section{Provider A}

Your company has received an offer for a construction power plant that will cost 100,000 €. As provider $\mathrm{A}$ is known for its quality maturity of an investment is 10 years, meaning that after 10 years the solar plant will stop working.
Accounting department had also prepared a plan of cash flows for entire investment maturity (see Table 16.2).

\section{Provider B:}

Your company had also received another competitive offer from provider B. Provider B is cheaper, but the quality of their solar plants is also a bit lower, so investment maturity, in this case, is only 7 years. Accounting department had prepared a plan of cash flows for entire investment maturity (see Table 16.3).

\section{Provider C}

One of your employees has suggested that there is also a possibility to get in contact with a provider that can construct a wind power plant. You have contacted this provider. Based on the received offer wind power plant will cost you 90,000 $€$. Cash flows are presented in Table 16.4.

Table 16.2 Investment alternative - provider A (solar plant)

\begin{tabular}{|c|c|c|c|c|c|c|c|c|c|c|c|c|}
\hline \multirow{2}{*}{$\begin{array}{l}\text { Efficiency based } \\
\text { on location }\end{array}$} & \multirow{2}{*}{$\begin{array}{l}\text { Investment } \\
\text { amount }\end{array}$} & \multirow[b]{2}{*}{ Cash flows } & \multicolumn{10}{|c|}{ Year } \\
\hline & & & 1 & 2 & 3 & 4 & 5 & 6 & 7 & 8 & 9 & 10 \\
\hline \multirow[t]{2}{*}{$1 / 3$} & \multirow[t]{2}{*}{$-100,000$} & $\begin{array}{l}\text { Revenues } \\
\text { (savings) }\end{array}$ & \multicolumn{10}{|c|}{17,000} \\
\hline & & $\begin{array}{l}\text { Maintenance } \\
\text { cost }\end{array}$ & 0 & 0 & 0 & 1500 & 1500 & 2500 & 2500 & 2500 & 3500 & 3500 \\
\hline \multirow[t]{2}{*}{$2 / 3$} & \multirow[t]{2}{*}{$-100,000$} & $\begin{array}{l}\text { Revenues } \\
\text { (savings) }\end{array}$ & \multicolumn{10}{|c|}{21,000} \\
\hline & & $\begin{array}{l}\text { Maintenance } \\
\text { cost }\end{array}$ & 0 & 0 & 0 & 1500 & 1500 & 2500 & 2500 & 2500 & 3500 & 3500 \\
\hline \multirow[t]{2}{*}{$3 / 3$} & \multirow[t]{2}{*}{$-100,000$} & $\begin{array}{l}\text { Revenues } \\
\text { (savings) }\end{array}$ & \multicolumn{10}{|c|}{28,000} \\
\hline & & $\begin{array}{l}\text { Maintenance } \\
\text { cost }\end{array}$ & 0 & 0 & 0 & 1500 & 1500 & 2500 & 2500 & 2500 & 3500 & 3500 \\
\hline
\end{tabular}

Table 16.3 Investment alternative - provider B (solar plant)

\begin{tabular}{|c|c|c|c|c|c|c|c|c|c|}
\hline \multirow{2}{*}{$\begin{array}{l}\text { Efficiency based on } \\
\text { location }\end{array}$} & \multirow{2}{*}{$\begin{array}{l}\text { Investment } \\
\text { amount }\end{array}$} & \multirow[b]{2}{*}{ Cash flows } & \multicolumn{7}{|c|}{ Year } \\
\hline & & & 1 & 2 & 3 & 4 & 5 & 6 & 7 \\
\hline \multirow[t]{2}{*}{$1 / 3$} & \multirow[t]{2}{*}{$-80,000$} & $\begin{array}{l}\text { Revenues } \\
\text { (savings) }\end{array}$ & \multicolumn{7}{|c|}{16,500} \\
\hline & & Maintenance cost & 500 & 500 & 1000 & 1000 & 1500 & 1500 & 1500 \\
\hline \multirow[t]{2}{*}{$2 / 3$} & \multirow[t]{2}{*}{$-80,000$} & $\begin{array}{l}\text { Revenues } \\
\text { (savings) }\end{array}$ & \multicolumn{7}{|c|}{22,000} \\
\hline & & Maintenance cost & 500 & 500 & 1000 & 1000 & 1500 & 1500 & 1500 \\
\hline \multirow[t]{2}{*}{$3 / 3$} & \multirow[t]{2}{*}{$-80,000$} & $\begin{array}{l}\text { Revenues } \\
\text { (savings) }\end{array}$ & \multicolumn{7}{|c|}{29,500} \\
\hline & & Maintenance cost & 500 & 500 & 1000 & 1000 & 1500 & 1500 & 1500 \\
\hline
\end{tabular}


Table 16.4 Investment alternative - provider $\mathrm{C}$ (wind power plant)

\begin{tabular}{|c|c|c|c|c|c|c|c|c|c|c|c|c|}
\hline \multirow{2}{*}{$\begin{array}{l}\text { Efficiency based on } \\
\text { location }\end{array}$} & \multirow{2}{*}{$\begin{array}{l}\text { Investment } \\
\text { amount }\end{array}$} & \multirow[b]{2}{*}{ Cash flows } & \multicolumn{10}{|c|}{ Year } \\
\hline & & & 1 & 2 & 3 & 4 & 5 & 6 & 7 & 8 & 9 & 10 \\
\hline \multirow[t]{2}{*}{$1 / 3$} & \multirow[t]{2}{*}{$-90,000$} & $\begin{array}{l}\text { Revenues } \\
\text { (savings) }\end{array}$ & \multicolumn{10}{|c|}{15,000} \\
\hline & & $\begin{array}{l}\text { Maintenance } \\
\text { cost }\end{array}$ & 0 & 0 & 5000 & 0 & 0 & 5000 & 0 & 0 & 5000 & 0 \\
\hline \multirow[t]{2}{*}{$2 / 3$} & \multirow[t]{2}{*}{$-90,000$} & $\begin{array}{l}\text { Revenues } \\
\text { (savings) }\end{array}$ & \multicolumn{10}{|c|}{19,500} \\
\hline & & $\begin{array}{l}\text { Maintenance } \\
\text { cost }\end{array}$ & 0 & 0 & 5000 & 0 & 0 & 5000 & 0 & 0 & 5000 & 0 \\
\hline \multirow[t]{2}{*}{$3 / 3$} & \multirow[t]{2}{*}{$-90,000$} & $\begin{array}{l}\text { Revenues } \\
\text { (savings) }\end{array}$ & \multicolumn{10}{|c|}{25,000} \\
\hline & & $\begin{array}{l}\text { Maintenance } \\
\text { cost }\end{array}$ & 0 & 0 & 5000 & 0 & 0 & 5000 & 0 & 0 & 5000 & 0 \\
\hline
\end{tabular}

\subsubsection{Deliverables}

You need to provide us with your final decision supported by your calculations. Then, your calculations will be cross-checked by the game masters.

\subsubsection{Spationomy Dragons' Den// Dober Posel//Den D//Die Höhle der Löwen}

The Dragons' Den was always the last round, where the main objective for students was to:

1. Present their project in the best light

2. Get the investment from the investors (teachers)

3. Calculate, how much is their business worth, to set the optimal ratio between the percentage they will give to the investor in return for his/her money.

This round was inspired by successful TV series, broadcasted in the United Kingdom under the name "Dragons' Den", in the USA as "Shark Tank", in Czechia as "Den D", in Slovenia as "Dober Posel", and in Germany as "Die Höhle der Löwen", and in more than other 30 countries worldwide. Originally, the TV series format was established in Japan as a "The Tigers of Money". Ordinary people with interesting ideas and business plans presented their products to wealthy investors to get investment for their entrepreneurship.

\subsubsection{The Rules}

\section{Rule 1: The Pitch}

Entrepreneurs (Students) must start the meeting by stating their name, the name of the business, the amount of money (up to 1 M EUR) they are pitching for and the percentage of equity they are willing to give away in their company. They must follow this with a pitch of up to $3 \mathrm{~min}$. If it exceeds 3 min, the Dragons (Teachers) can stop entrepreneurs at any point, but they cannot interrupt the initial pitch.

\section{Rule 2: The Questions and Answers}

Entrepreneurs DO NOT have to answer all the questions asked, but what they do or do not choose to answer may affect the outcome - for example, if they refuse to reveal net profits. They may ask the Dragons any questions that help them determine whether they are suitable investors for their business.

\section{Rule 3: Opting 'Out'}

Also, once a Dragon has declared his or herself 'out', they MUST NOT re-enter negotiation on the deal, and unless there is a compelling reason, they should remain quiet and leave the others to pursue the negotiations. 


\section{Rule 4: Investments}

The entrepreneur must secure at least the total amount they have asked for at the beginning of the pitch. If a Dragon offers less than the full amount, the entrepreneur must try and make up the total by securing an investment from one or more of the remaining Dragons. Each entrepreneur must leave the Den with at least the full amount they asked for, or they exit emptyhanded. The entrepreneur can negotiate more money than was initially requested, as this is usually to redress the sticking point of an entrepreneur giving up more equity than was initially offered.

\section{Rule 5: Multi-Dragon Investments}

Each Dragon is working as an individual investor. The Dragons can invest as little or as much of their own money as they want. It is up to the entrepreneur to persuade them to match the required investment or pledge to invest a portion thereof. As above, it is acceptable for the entrepreneur to seek investment from more than one investor to make up the total amount required. A full investment may involve between one and five parties.

\section{Rule 6: Refusing Investments}

An entrepreneur can refuse investment from a Dragon if they think they are an unsuitable investor or the deal on the table isn't right for them.

\section{Rule 7: The Deal}

The deal agreed on the day is an unwritten agreement that depends on due diligence checks, and relies on the integrity of both investor and entrepreneur to freely enter the transaction and be fully committed to seeing it through. However, the deal is solely between the Dragon and the entrepreneur, and after additional meetings, if an agreement cannot be reached, neither party is legally obliged to complete the deal.

\subsubsection{Deliverables}

Each team tries to negotiate the investment within the most profitable conditions. If the team refuses the investment, it does not affect their overall scoring. This round is evaluated base on a mixture of criteria - e.g. quality of presentation, negotiation style, timing, self-promotion, marketing skills and so on.

\subsection{Evaluation of the Simulation Game}

This chapter is dedicated to the qualitative assessment of the Spationomy simulation game. The first part is devoted to the internal feedback among staff members and is mainly based on personal experiences with the game concept, and technical and practical findings from playing itself. The second part of this chapter focuses on the evaluation from students which was conducted via an online questionnaire after at least one month of playing the game. We provide a summary of students' answers and feedback, grouping it into four main aspects of the game.

\subsubsection{Staff Evaluation}

From the process of individual rounds creation, we have to mention that the idea of developing several versatile and self-independent rounds has been very pragmatic. Since all of the Spationomy team members focus on different topics, moreover grouped by their institutions/departmental field of study (i.e. geography, geoinformatics, economy, management, business informatics, quantitative methods), it is a very complex task to coordinate and to develop flawless "chain" of follow-up rounds. Therefore, we applied an approach where each project partner developed their round (or more rounds) that do not need results from the previous round as an input, except the very first initial round and virtual cash balance. Also, every single game round creates some intermediate output/result that is used in a next game round (again, only teams' cash balance is counted every round). Therefore, when developing such complex simulation games requiring interaction and immediate action, the versatility and independence of individual rounds 
is highly recommended. Besides, it is possible to include a "dramatic" aspect into the game dynamics by drawing rounds by chance.

Another interesting feature of the simulation game, from the staff perspective, was that the students were immediately engaged and keen to play. The reason why playful learning and teaching is perceived to be a more effective method than regular classes is given in Sect. 16.1. But there is another important aspect of explaining students' quick engagement. It is rather simple, coming from the Spationomy project design itself - students play the simulation game at the very end of the project after they went through all the activities that involve cooperation within the team, and supports healthy competition with other teams. Therefore, students feel motivated to play against others and win the game, also due to strong bonds within the team they built during the project.

On the other hand, the simulation game concept represented a new experience for most of the staff members, and many more or less serious problems evolving even during the game itself had to be solved on the spot. With more previous experiences these issues could have been prevented, but fortunately, none of these problems endangered the game. Examples of "hot" issues are listed in the following points which are based on authentic notes and commentaries recorded during the game by the "observing" staff members:

- Can't build a factory in an existing building not even inside

- Wrong price of bikes

- Cost of pollution - $\min / \max$

- 1 round $=1$ year

- Bonuses work with at least one location buffer

- Save everything to give us at the end of the game (gdb, pictures, maps, calculations, etc.)

- Flood zones were not $100 \%$ real

- Cutting the tree in order to build the factory is at no cost? - should not be

- Do back-ups - computers wipe out every night (in Maribor)
- How to collect and share data - google form + whole project - Dropbox/Google Drive link

- No SW for graphics editing - logos, etc.

- Be EXACT about size!!!

- Some groups did wrong calculations - we should assign points based on that

- Relative criteria of performance measurement!!!!

- Floods according to the DTM

- Zone 4 in floods was missing, so they were not sure, how to intersect without the zone

- Figure out how students can easily deliver the outcomes to us!

All the comments above come from direct observations of the students' playing the game, biases in rules or guides we encounter, as well as from students questions. We now provide a brief commentary on some of the points. For example, the first point about the factory placement students are smart and creative in the sense of finding gaps in rules, so they asked if they can build their bicycle factory in a quadrangle of an existing block of flats (in the inner part/courtyard of buildings). Although it is a simulation game, we had to avoid such unrealistic actions. We also had to justify several mistakes/uncertainties "onthe-fly", such as the wrong price of bicycles, adjusting values for pollution costs, the timing of rounds, bonuses, figuring out how students will deliver results to game master in the most effective way (via email, USB drives, sharing system etc.). From the technical point of view, we faced difficulty with computers in Maribor (Slovenia) which are set to be rebooted and formatted overnight to be "clean" for another days' lecture. Therefore, every workstation that was used had to be backed-up before leaving the room. Another technical drawback was a software availability - although students were taught in specific software tools by intention during the Spationomy course, they wanted to use the software they are more familiar with. For example, some of the geoinformatics students were more skilled in ArcGIS platform from their regular studies, but due to lack of licenses in Maribor, 
computers were equipped by open source QGIS. The same happened with a statistical software usage - SPSS platform was substituted for open-source R Project.

In general, from the staff's perspective, the preparatory phase of the simulation game was demanding in the sense of careful design of individual rounds. We had limited experiences to anticipate potential problems if the round tasks are understandable if the data sources are rich enough, and especially the timing of individual rounds could not be estimated. However, in most cases, the time allocation of $90 \mathrm{~min}$ was sufficient. Fortunately, it never happened that a team is not able to deliver desired outputs at the end of the round. There was also uncertainty in the time we, as game masters, need to evaluate/score individual rounds. Since we did it after each round, it had to be done quickly, because the final cash balance of the team was needed for next rounds (the cash balance was the only "dependent" interweaving red-line in otherwise versatile and independent rounds). Before the first simulation gameplay, we were unable to estimate the evaluation time, but because of prepared spreadsheets (Fig. 16.3), we managed to provide quick feedback to students (usually within $30 \mathrm{~min}$ ).

\subsubsection{Students Evaluation}

After each year, the student evaluation of the simulation game was organised. Students were asked to evaluate their decision-making process within the team, simulation game design; and technical aspects of the game. Furthermore, gender, level of study, and university were collected as optional information. In total, 33 students replied in the survey, 20 students in the first year and 13 in the second year of the project. In general, students did not have much prior experience with simulation games (85\% of students).

\subsubsection{Decision Making}

Although it was different in each round, and the answers varied from $53,8 \%$ to $84,6 \%$, the students agreed that "Decision making was done collectively (based on majority agreement)".
Other options were "The team was indecisive, and we used "trial-and-error" method" and "There was one leader, and we followed his/her instructions (decision made by the leader)". The percentage of the remaining two possible answers changed depending on the structure and complexity of the task. Regardless the decision-making process, majority of the students indicated that they were satisfied with the final decision of their team - on a 5-point Likert scale 72\% students marked 4 or 5 in terms of their satisfaction, where one was lowest, and five was highest.

\subsubsection{Spationomy Balance}

The inherent issue of the whole project - how to connect geographical tasks with economic tasks was also present within the simulation game. We aimed to combine tasks in each round, so students feel that they have something to contribute with. Of course, not every round can be designed to involve equally students from two study fields. Therefore we asked them, "How did cooperation between "geo" and "eco" team-members go on (for all rounds)?". The answers surprised us in a positive sense, $69,7 \%$ of students stated that "Cooperation and decision making was wellbalanced".

\subsubsection{Using the Knowledge from the Project}

In the evaluation form, there were two questions focused on how did and will the students use the knowledge gain through the project cycle. The first question "Did you use knowledge and skills acquired within the previous Spationomy activities for the simulation game?" was answered very positively with $48 \%$ answering "Yes" and $52 \%$ answering "Some of it", leaving $0 \%$ answering "No". The second question focusing of their future use of knowledge gained during the project formulated as: "Did you find the knowledge, skills, and experiences acquired during simulation game useful for your future studies/profession?", $42 \%$ of students answered "Yes", 55\% answered "Some of it" and 3\% answered "Hope so", leaving again $0 \%$ for an answer "No". In general, students were positive about the usability of new skills and knowledge gained during the 
Spationomy project, which was very motivating feedback for the organisers. Students would also like to have even more links between economic and GIScience activities, as described by one of the students: "Maybe more focus on the interconnection between "geo" and "eco" activities." (male, MVSO).

\subsubsection{Playfulness of the Simulation Game Rounds}

One of the aspects of the simulation game was the playfulness (Poplin 2014) of the process. We have asked students "How playful was each round?" in the evaluation form, and the students had the opportunity to answer again via five-point Likert scale (1 lowest -5 highest). The average value in the first year was 4.0, in the second year 3.9. So the rounds were considered quite playful in general. Nevertheless, there was a slight difference. While the least playful round (data filtering) had an average value of 3.0, the most playful round (the Dragon's Den) had an average value of 4.5. Students tend to assign more positive values to the tasks, where they interact with other groups or where there is an element of surprise. This is also reflected by one of the students in the evaluation "add an unexpected situation (for example Economic Crisis)" (male, UPOL). When asked, which features did students find the most exciting, in each year the most answers got "decision making - tactics and strategy".

\subsection{Summary}

This last part of the book was devoted to the Spationomy simulation game concept. First, we provided a comprehensive theoretical background of geographical/business simulation games with a focus on educational purposes in Sect. 16.1. From the literature review, it is clear that gamification of an education process brings added value to the learning and teaching experience to both learners and teachers. If there is a gaming or at least playful feature in a class, it is usually very highly encouraging students attention, engagement, and finally stimulates their learning outcomes. In general, any kind of gaming or playful activity entails more relevant and attractive pedagogy. However, it has to be noted that we mostly refer to "serious" gaming for educational purposes (not gaming solely for personal amusement). Lately, we described the most important features of the Spationomy simulation game concept. We touched the topics of students' teams' preparations, initial simulation game settings, time management of the game, scoring and ranking system and other aspects of the game.

In Sect. 16.2, we shared original simulation game rounds description and task. It is presented exactly in the form that it was given to students, in order to provide an authentic "feeling" about the simulation game rounds. We must mention that oral explanations have always complemented the written game round description. Sometimes, students expressed their uncertainty about the game rounds, so further clarifications from the game round creator were provided. Generally, the game rounds settings and documentation were sufficient enough, so we did not experience any serious issues in playing the simulation game.

Finally, Sect. 16.3 focuses on the evaluation of the Spationomy simulation game. We described a staff reflection on the simulation game. For all staff members, it was the first time experience conducting a simulation game. Therefore, it is more an authentic testimony about the simulation game rather than systematic evaluation. By contrast, the section devoted to students' evaluation is solely based on the formal questionnaire-based evaluation. Staff and students' evaluation together serve as unique feedback on the simulation game concept (and playing the game itself) which definitely helps to develop the game further use.

\section{References}

Abt, C. (1969). Games for learning (Occasional Paper No. 7). Cambridge, MA: Educational Services Inc..

Ampatzidou, C., \& Gugerell, K. (2019). Mapping game mechanics for learning in a serious game for the energy transition. International Journal of E-Planning Research (IJEPR), 8(2), 1-23. 
Conolly, G. (1981). The use of four selected games in a tertiary geography programme. Journal of Geography in Higher Education, 5(2), 121-132.

Crawford, C. (1982). The art of computer game design. Berkeley: McGraw-Hill.

Egenfeldt-Nielsen, S., Smith, J. H., \& Tosca, S. P. (2008). Understanding video games: The essential introduction. New York: Routledge.

Faria, A. J., Hutchinson, D., Wellington, W. J., \& Gold, S. (2009). Developments in business gaming: A review of the past 40 years. Simulation \& Gaming, 40(4), 464-487.

Gagnon, J. H. (1987). Mary M. Birshtein: The mother of Soviet simulation gaming. Simulations and Games, 18(1), 3-12.

Gould, P. R. (1963). Man against his environment: A game-theoretic framework. Annals of the Association of American Geographers, 53(3), 290-297.

Healey, M., \& Jenkins, A. (2000). Kolb's experiential learning theory and its application in geography in higher education. Journal of Geography, 99(5), 185-195.

Heath, R. (2017). Geography games and simulations, geographical association conference workshop 2017. Available from: http://themapoff.wixsite.com/mapoff/ ga-conf-2017-games

Juul, J. (2003). The game, the player, the world-Looking for a heart of gameness. In Paper presented at the level up-Digital games research conference. Utrecht.

Kim, M., \& Shin, J. (2016). The pedagogical benefits of SimCity in urban geography education. Journal of Geography, 115(2), 39-50.

King, R. (1981). To play or not to play: An introduction to games and simulations in geography teaching: A JGHE special feature. Journal of Geography in Higher Education, 5(2), 111-112.

List, J., \& Bryant, B. (2014, March). Using Minecraft to encourage critical engagement of geography concepts. In Society for information technology and teacher education international conference (pp. 2384-2388). Chesapeake: Association for the Advancement of Computing in Education (AACE).
McCormick, J. (1972). Simulation and gaming as a teaching method. Programmed Learning and Educational Technology, 9(4), 198-205.

Minović, M., Milovanović, M., \& Starcevic, D. (2011, September). Literature review in game-based learning. In The world summit on knowledge society (pp. 146-154). Berlin/Heidelberg: Springer.

Nebel, S., Schneider, S., \& Rey, G. D. (2016). Mining learning and crafting scientific experiments: A literature review on the use of Minecraft in education and research. Journal of Educational Technology \& Society, $19(2), 355$.

Nesbitt, W. A. (1971). Simulation games: The social studies classroom (Vol. 1, No. 1). New York: Crowell.

Poplin, A. (2014). Digital serious game for urban planning: "B3-Design your marketplace!". Environment and Planning B: Planning and Design [online], 41(3), 493-511. B.m.: London: Sage.

Raghothama, J., \& Meijer, S. A. (2013). A review of gaming simulation in transportation. In The international simulation and gaming association conference (pp. 237-244). Cham: Springer.

Salen, K., Tekinbaş, K. S., \& Zimmerman, E. (2004). Rules of play: Game design fundamentals. Cambridge MA: MIT Press.

Scarlett, M. (2015). Gaming geography: Using Minecraft to teach essential geographic skills. In Society for information technology and teacher education international conference (pp. 838-840). Chesapeake: Association for the Advancement of Computing in Education (AACE).

Strum, I. (1969). Zeiler, R.: Games for school use. New York: Centre for Educational Research.

Twelker, P. A. (1970). Some reflections on the innovation of simulation and gaming. In Paper presented at the first annual conference of the Society for Academic Gaming and Simulation in Education and Training, Berkshire College of Education, Reading.

Walford, R. (1981). Geography games and simulations: Learning through experience. Journal of Geography in Higher Education, 5(2), 113-119.

Open Access This chapter is licensed under the terms of the Creative Commons Attribution 4.0 International License (http://creativecommons.org/licenses/by/4.0/), which permits use, sharing, adaptation, distribution and reproduction in any medium or format, as long as you give appropriate credit to the original author(s) and the source, provide a link to the Creative Commons licence and indicate if changes were made.

The images or other third party material in this chapter are included in the chapter's Creative Commons licence, unless indicated otherwise in a credit line to the material. If material is not included in the chapter's Creative Commons licence and your intended use is not permitted by statutory regulation or exceeds the permitted use, you will need to obtain permission directly from the copyright holder. 